\title{
Assessing the Sustainability Performance of Coffee Farms in Vietnam: A Social Profit Inefficiency Approach
}

\author{
Daniel Gaitán-Cremaschi ${ }^{1, *,+}$, Frits K. van Evert ${ }^{2}$ (D) Don M. Jansen ${ }^{2, \ddagger}$, \\ Miranda P. M. Meuwissen ${ }^{1}$ and Alfons G. J. M. Oude Lansink ${ }^{1}$ \\ 1 Business Economics Group, Wageningen University \& Research, PO Box 47, 6700 AA Wageningen, \\ The Netherlands; miranda.meuwissen@wur.nl (M.P.M.M.); alfons.oudelansink@wur.nl (A.G.J.M.O.L.) \\ 2 Agrosystems Research, Wageningen University \& Research, PO Box 16, 6700 AA Wageningen, \\ The Netherlands; frits.vanevert@wur.nl (F.K.v.E.); don@agri-logic.nl (D.M.J.) \\ * Correspondence: daniel.gaitancremaschi@wur.nl; Tel.: +31-(0317)-481-191 \\ + Current address: Farming Systems Ecology Group, Wageningen University \& Research, \\ PO Box 4306700 AK, Wageningen, The Netherlands. \\ $\ddagger$ Current address: Agri-Logic, Bennekomseweg 456866 DB, Heelsum, The Netherlands.
}

Received: 7 September 2018; Accepted: 13 November 2018; Published: 16 November 2018

\begin{abstract}
If we aim to increase the sustainability of farming, we must be able to measure the sustainability of individual farms and relate this sustainability to the characteristics of the farm and its management. We hypothesized that (i) sustainability can be expressed using social profit, and (ii) socio-economic characteristics and management practices of farms explain differences in sustainability. The objective of our work was to provide empirical evidence for these hypotheses. Data was collected data over two years from 361 coffee farms in Vietnam to calculate social profit. We found that the average social profit of farms was 2300 USD. The main source of social profit inefficiency is the sub-optimal allocation of resources and levels of production. Statistical association between the set of socio-economic characteristics and management practices and social profit inefficiency shows that social profit inefficiency is increased (sustainability is decreased) by larger distances from the coffee farm to the closest town/city center and to the closest coffee factory/traders and by a high frequency of spraying. On the other hand, sustainability is increased when coffee producers belong to the ethnic group JoRai, when using more hired labor and frequency, and when there are a larger number of fertilizing and pruning activities. We conclude that social profit inefficiency can be used to summarize sustainability.
\end{abstract}

Keywords: social profit inefficiency; relative sustainability performance; externalities

\section{Introduction}

Coffee is one of the most widely traded agricultural commodities in the world, produced by 20 to 25 million producers in more than 14 countries [1,2]. Vietnam has a $12 \%$ to $15 \%$ share in the world market and is the second largest exporter of coffee after Brazil [1,3]. In 2013, coffee exports accounted for approximately $2 \%$ of Vietnam's gross domestic product (GDP) [4] and $17 \%$ of all commodity exports [3]. Currently, an area of 500,000 hectares is planted with coffee, with a production of approximately one million tons [3]. Vietnam produces coffee from two species, Robusta and Arabica; $90 \%$ of production is from Robusta [5]. Approximately $80 \%$ of coffee is produced in four provinces located in the Central Highlands of Vietnam, i.e., Dak Lak, Lam Dong, Dak Nong and Gia Lai, typically by smallholder farmers that obtain the largest part of their income from coffee production [6-8]. Coffee production is important for the Vietnamese economy and crucial for the Central Highlands. However, the unshaded 
monoculture farming system used by most producers generates harmful environmental impacts. Coffee farming in Vietnam requires high application rates of fertilizers [9]. High fertilization rates are associated with high rates of emission of greenhouse gases and leaching of nutrients to water bodies. Emission of greenhouse gases contributes to climate change, whereas leaching of nutrients can have adverse effects on biodiversity and water quality [10]. Chemical pesticides are used to control fungal diseases, pests and a variety of weeds. Improper application of chemical pesticides in coffee production can have adverse effects on the environment, biodiversity, and human health, especially farm workers [11,12]. Ensuring adequate production levels requires irrigation of coffee plantations [13]. Experience in Vietnam shows that farmers often use more water than needed [9]. Over-irrigation is especially harmful during drought years, when water resources (from groundwater and basins) are depleted [7]. Scarcity of water may drive additional investments for construction of deeper wells and negatively affect ecosystems.

The profitability of coffee farming is under pressure, due to increasing production costs for fertilizers and labor [8], as well as the volatility of coffee prices in the world market [3,14]. At low coffee price levels, the revenues of coffee production may not cover production costs, and other crops, such as pepper, may then be more profitable. This situation leads to (partial) replacement of coffee plantations by other crops or to the abandonment of coffee farms [3], impacting, in turn, on the livelihood of rural communities, especially the relatively poor.

The challenges facing coffee production in Vietnam center around the three pillars of sustainability, i.e., environmental, economic, and social. A first step towards achieving sustainable coffee production in Vietnam is an integrated assessment of the current relative sustainability level of coffee farms. A following step is to explore how the socio-economic characteristics and management practices of farmers affect the sustainability level. The most common approach for sustainability assessment is the use of a diverse set of performance indicators, which measure the extent to which sustainability goals are achieved [15]. Quantification of a set of performance indicators is feasible in many cases. However, when using isolated indicators reflecting different aspects of sustainability, decision makers must use their own weighing factors to evaluate overall sustainability. These weighing factors reflect implicit and complicated trade-offs between sustainability issues that are not normally in decision makers' mindsets, e.g., greenhouse gas emissions versus profitability $[16,17]$. To overcome these difficulties, several authors have proposed using a single metric, namely monetary value, to express the performance on the different aspects of sustainability [18-22]. We follow this approach and propose using an integrated sustainability performance measure labelled social profit, that is, the profit of the farm system (revenues minus production costs) adjusted for the external costs of production (environmental and social dimensions of sustainability) $[17,21,23]$. Using this approach, a farm that achieves a positive social profit (farm revenues are higher than production and external costs) is considered to perform sustainably. This approach assumes a weak sustainability perspective, implying that man-made capital can replace any component of the natural and social capital [24]. Social profit is additive, i.e., the social profit of a sector in agriculture (e.g., the coffee sector) is the sum of the social profit scores of the individual farms.

Some studies have assessed the production and external costs of agricultural production, mostly at the country level, see for example [21,25-29]. Moreover, several studies have employed Data Envelopment Analysis (DEA) and the Directional Distance Function (DDF) to measure agricultural total factor productivity, technical inefficiency and eco-efficiency at farm level, see for example [30-35]. However, the literature lacks empirical studies assessing social profit inefficiency, which is the extent to which farms fail to obtain the maximum attainable social profit given technology and prices for inputs, outputs and externalities. In this paper, we address this knowledge gap and employ the profit function and the DDF to construct a measure of social profit inefficiency, i.e., the Nerlovian social profit inefficiency (NI) indicator. A sustainability performance assessment using the NI indicator would enable the identification of sources of inefficiency in attaining social profit as a first step to highlight potential areas where sustainability of agricultural production can be improved. That is, the 
identification of the extent to which the current production potential is used, the sub-optimal choice of the scale of the operations, and the sub-optimal allocation of resources and pollution at given prices for outputs and inputs and the economic value of externalities.

Furthermore, socio-economic characteristics (e.g., education, age, number of family members, socio-economic income level group) and management practices (e.g., pruning, weeding, spraying, fertilization), have been shown to be important factors affecting sustainability of farms [7,36-40]. However, the impact of these characteristics on social profit inefficiency has not been investigated so far.

In line with the preceding considerations, the objectives of this study are to: (i) assess the current relative sustainability level of a sample of coffee farms in Vietnam in terms of their social profit and to identify the sources of social profit inefficiency, and (ii) detect statistical associations between a set of socio-economic characteristics and management practices and the relative sustainability level of farms. For this empirical study, we hypothesize that social profit inefficiency and its components are positively associated with the variables related to distance, spraying, and ethnic group, and that the inefficiency scores are negatively associated with family members, hired labor, pruning, fertilizing, weeding, and education.

This assessment will provide insights and will identify opportunities to improve sustainability of coffee production in Vietnam.

\section{Methods: Measuring Relative Farm Sustainability Using the Nerlovian Social Profit Inefficiency (NI) Indicator}

\subsection{Nerlovian Social Profit Inefficiency (NI) Indicator}

Suppose there are $k=1, \ldots, K$ coffee farms (termed decision-making units-DMUs) using $N$ inputs and $D$ fixed inputs to produce $M$ outputs. In the production process, $J$ negative externalities are produced, such as waste and pollution. Let vectors $y=\left(y_{1}, y_{2}, \ldots y_{M}\right) \in \Re_{+}^{M}, x=\left(x_{1}, x_{2}, \ldots x_{N}\right) \in$ $\Re_{+}^{N},\left(f_{1}, f_{2}, \ldots f_{D}\right) \in \Re_{+}^{D}$, and $b=\left(b_{1}, b_{2}, \ldots b_{J}\right) \in \Re_{+}^{J}$ represent the outputs, inputs, fixed inputs, and negative externalities, respectively. The production possibility set is defined as the set of all feasible input-output-externality vectors and is represented as:

$$
T=\{(y, x, f, b): x, f \text { can produce } y, b\}
$$

If the $k$-th DMU faces output prices represented by the vector $p=\left(p_{1}, p_{2}, \ldots p_{M}\right) \in \Re_{+}^{M}$, input prices by the vector $w=\left(w_{1}, w_{2}, \ldots w_{N}\right) \in \Re_{+}^{N}$, fixed input prices by vector $v=\left(v_{1}, v_{2}, \ldots v_{D}\right) \in \Re_{+}^{D}$, and external unit cost estimates for the externalities represented by the vector $r=\left(r_{1}, r_{2}, \ldots r_{J}\right) \in \Re_{+}^{J}$, then the observed social profit is defined as:

$$
S P=p^{\prime} y-w^{\prime} x-f^{\prime} v-r^{\prime} b
$$

Considering that polluting inputs such as fertilizers and pesticides are not commonly priced at their full cost (private + social cost), the social profit calculation corrects for the improper pricing of these inputs by accounting for the externalities derived from their use. Hence, social profit is defined as revenues $\left(p^{\prime} y\right)$ minus conventional costs $\left(w^{\prime} x\right)$, fixed costs $\left(f^{\prime} v\right)$, and the external costs of production $\left(r^{\prime} b\right)$, where the externalities can be considered as output penalties that lower the social profit score. It should be noted that this paper focuses on environmental externalities and that strictly speaking the word "social" overstates the actual focus. We have chosen to use the more general term social profit to emphasize that the method allows for easy inclusion of social impacts, as well as environmental impacts.

To evaluate the efficiency with which the $k$-th DMU operates in terms of social profit, the observed social profit in Equation (2) is compared to the maximum social profit the DMU could attain given the current technology used by the sample of DMUs, the available levels of the fixed inputs $f$, and 
the (shadow) prices. The difference between the maximum attainable social profit and the observed social profit provides a measure of social profit inefficiency [41]. The maximum social profit for the $k$-th DMU is defined as:

$$
\Pi(p, w, r, f)=\max _{y, x, \mathrm{~b}}\left\{p^{\prime} y-w^{\prime} x-r^{\prime} b \mid(y, x, f, b) \in T\right\}=p^{\prime} y^{*}-w^{\prime} x^{*}-r^{\prime} b^{*}
$$

where $y^{*}, x^{*}$, and $b^{*}$ are the optimal output, input, and externality combinations that provide the maximum attainable social profit, given the production technology, prices (shadow), and the available levels of the fixed inputs. To provide a unit-free measure of social profit inefficiency [42,43], the Nerlovian social profit inefficiency (NI) is used. The NI is defined as the difference between the maximum social profit defined in Equation (3) and the observed social profit defined in Equation (2), normalized by the value of the directional vectors $g_{y} \in \Re_{+}^{M}, g_{x} \in \Re_{+}^{N}$, and $g_{b} \in \Re_{+}^{J}$ [40]. This normalization arises from the duality between the profit function and the DDF, providing the basis for its decomposition [41] (For a detailed explanation of this dual relation see [41]). The DDF and the directional vector are discussed in more detail in Section 2.2.1. Accordingly, the NI indicator for the $k$-th DMU is defined as:

$$
N I\left(p, w, r, y, x, f, b ; g_{y}, g_{x}, g_{b}\right)=\frac{\Pi(p, w, r, f)-\left(p^{\prime} y-w^{\prime} x-r^{\prime} b\right)}{p^{\prime} g_{y}+w^{\prime} g_{x}+r^{\prime} g_{b}}
$$

In this approach, the $k$-th DMU is performing sustainably, i.e., is zero Nerlovian social profit inefficient, if the observed social profit is equal to the maximum highest attainable social profit. In other words, when NI (.) $=0$. If the DMU is Nerlovian social profit inefficient, $N I()>$.0 , then the DMU has scope to improve its sustainability performance.

Definition of the NI indicator as the difference between the maximum social profit and the observed social profit, resolves problems of profit inefficiency measures, which cannot handle zero and negative observed profits [44]. In addition, the NI has decomposition power [44], and therefore, it can be used to identify the contributions of output-specific, input-specific, and externality-specific inefficiencies:

$$
N I\left(p, w, r, y, x, f, b ; g_{y}, g_{x}, g_{b}\right)=\frac{p^{\prime}\left(y^{*}-y\right)}{p^{\prime} g_{y}+w^{\prime} g_{x}+r^{\prime} g_{b}}+\frac{w^{\prime}\left(x-x^{*}\right)}{p^{\prime} g_{y}+w^{\prime} g_{x}+r^{\prime} g_{b}}+\frac{r^{\prime}\left(b-b^{*}\right)}{p^{\prime} g_{y}+w^{\prime} g_{x}+r^{\prime} g_{b}}
$$

Decomposition shows whether outputs are under- or over-produced, inputs are under- or over-used, and whether externalities are below or above optimum levels. Hence, decomposition can help identify opportunities to improve the relative sustainability performance of farms. The inefficiency in social profit and the variable-specific contributions are illustrated in Figure 1, using a simple example with one input, one output, and one externality.

\subsection{Sources of Farm Sustainability}

2.2.1. Decomposition of the NI Indicator: Pure Technical Inefficiency (PTI), Scale Inefficiency (SI), and Allocative Inefficiency $(A I)$

Exploiting the dual relation between the profit function and the DDF, the NI indicator for the $k$-th DMU is decomposed into overall technical inefficiency (OTI) and allocative inefficiency (AI) [41]. The OTI, in turn, is decomposed into pure technical inefficiency (PTI) and scale inefficiency (SI):

$$
N I=O T I+A I=P T I+S I+A I
$$

The OTI component reflects the technical inefficiency relative to the best-practice frontier, assuming a production technology that exhibits constant returns to scale (CRS). It reflects the percentage by which a DMU could jointly increase the outputs and reduce the inputs and externalities, given 
the production technology $T$ [45]. If the DMU cannot make further improvements, it has zero technical inefficiency, and is therefore operating at the best-practice frontier [45]. Estimation of the OTI component requires the use of the DDF associated with an explicit direction in which technical inefficiency is measured. Choosing the directional vector enables the projection of the input, output, and externality vectors onto the production frontier as defined by the directional vector $g=\left(g_{y},-g_{x},-g_{b}\right)$. Formally, the DDF measuring technical inefficiency under CRS is defined as [45]:

$$
\text { OTI }=\vec{D}_{T}\left(y, x, f, b ; g_{y}, g_{x}, g_{b} \mid C R S\right)=\max \left\{\beta:\left(y+\beta g_{y}, x-\beta g_{x}, b-\beta g_{b}\right) \in T_{C R S}\right\}
$$

The $k$-th DMU is, overall, zero technically inefficient if $\vec{D}_{T}(y, x, f, b ; g \mid C R S)=0$ and overall technically inefficient if $\vec{D}_{T}(y, x, f, b ; g \mid C R S)>0$.

The OTI measure can be further examined by decomposition into PTI and SI. PTI is obtained by estimating Equation (7), assuming a production technology that exhibits variable returns to scale (VRS), as follows:

$$
P T I=\vec{D}_{T}\left(y, x, f, b ; g_{y}, g_{x}, g_{b} \mid V R S\right)=\max \left\{\beta:\left(y+\beta g_{y}, x-\beta g_{x}, b-\beta g_{b}\right) \in T_{V R S}\right\}
$$

The second component, $S I$, is computed as the difference between the values obtained from Equations (7) and (8). This measure reflects the extent to which the $k$-th DMU succeeds in choosing the optimal size of its operations, as follows:

$$
S I=\vec{D}_{T}\left(y, x, f, b ; g_{y}, g_{x}, g_{b} \mid C R S\right)-\vec{D}_{T}\left(y, x, b ; g_{y}, g_{x}, g_{b} \mid V R S\right)
$$

The AI component refers to the loss of potentially attainable social profit because of a sub-optimal choice on the mix of inputs, outputs, and externalities, given their corresponding (shadow) prices [46]. The AI component is derived as the residual of the difference between Equations (4), (8) and (9):

$$
A I=N I-P T I-S I
$$

The PTI, SI, and AI components are necessarily non-negative, which implies that if the $k$-th DMU has zero Nerlovian social profit inefficiency, then it must be purely technically efficient, scale efficient and allocatively efficient [46].

The concept of social profit inefficiency and its decomposition into the PTI and AI components is illustrated in Figure 1 using a simple example with two DMUs (A and B), one input $(x)$, one output $(y)$, one externality $(b)$, and prices $(w, p$ and $r)$. The social profit function $\pi=p y-w x-r b$ is rewritten in the form $y=(\pi+r b) / p+(w / p) x$, i.e., the equation of the isoprofit line with intercept $\pi+r b / p$ and slope $w / p$ that gives all input-output-externality combinations capable of producing social profit level $\pi$. The isoprofit line is tangent to the production technology $T$ at point $R$, where an optimal input-output combination $\left(y^{*}, x^{*}\right)$ maximizes social profit given their prices.

In the first case, $D M U^{A}$ is social profit inefficient, as the observed input-output combination $\left(y^{A}\right.$, $x^{A}$ ) generates a lower social profit than it could attain at point $\mathrm{Q}$, given prices and the production technology. The inefficiency in social profit for this DMU is attributable to pure technical inefficiency $\left(\mathrm{DMU}^{\mathrm{A}}\right.$ could increase the output and decrease the input in the direction defined by $\mathrm{g}=\left(g_{y}, g_{x}\right)$ to reach the production frontier at point $\mathrm{P}$ ), and allocative inefficiency (given the prices, $\mathrm{DMU}^{\mathrm{A}}$ is under-using the input and under-producing the output). An optimum combination would allow the $\mathrm{DMU}^{\mathrm{A}}$ to increase social profit, i.e., shift from point $P$ to point $Q$ on the isoprofit line.

In the second case, $\mathrm{DMU}^{\mathrm{B}}$ is also social profit inefficient. The observed input-output combination $\left(y^{B}, x^{B}\right)$ does not yield the maximum attainable social profit. This DMU has zero pure technical inefficiency, as it lies on the boundary of the production frontier. The inefficiency in social profit is only attributable to allocative inefficiency mainly caused by over-use of the input and over-production of 
the output. In this case, an optimum combination would allow the $\mathrm{DMU}^{\mathrm{B}}$ to increase social profit, i.e., shift from the boundary of the production frontier to point $S$ on the isoprofit line.

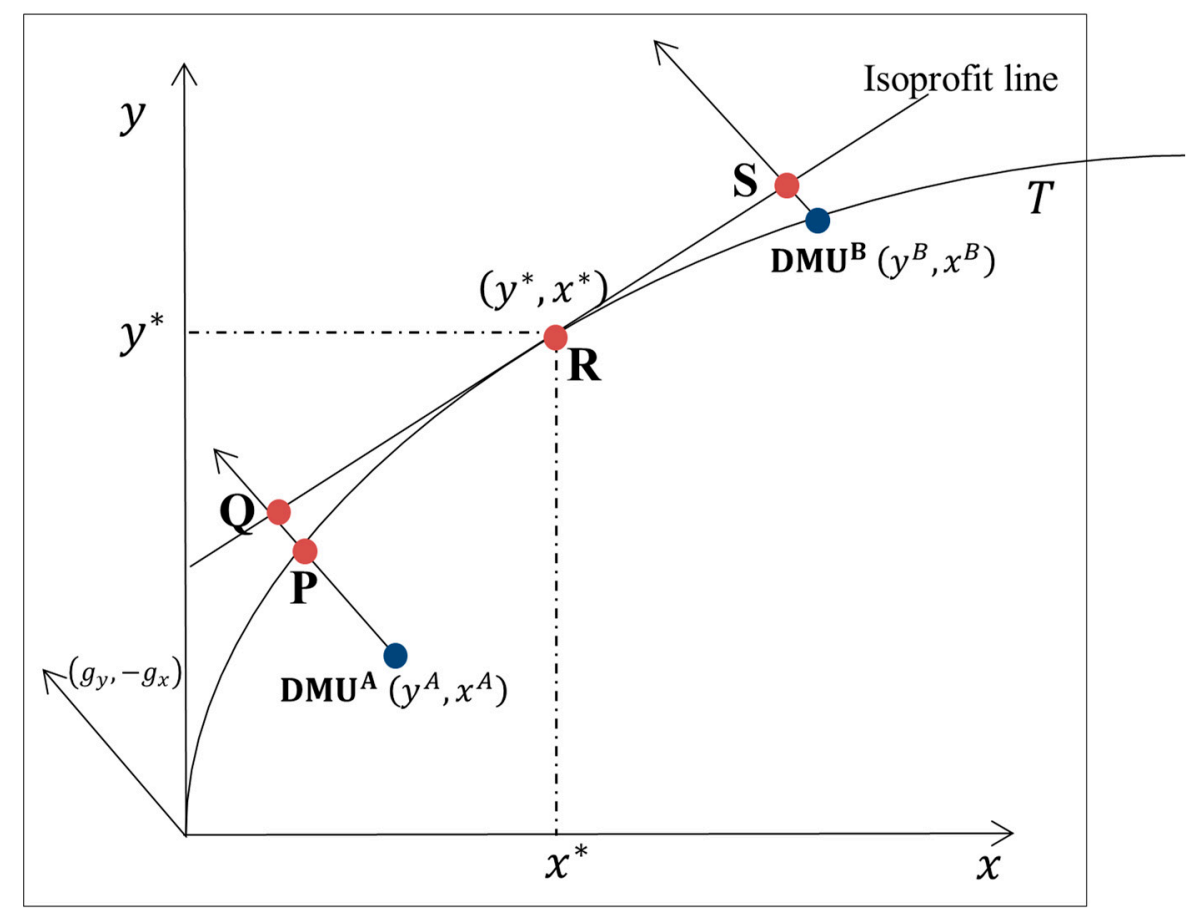

Figure 1. Inefficiency in social profit and the decomposition into pure technical inefficiency $(P T I)$ and allocative inefficiency $(A I)$.

Empirically, the profit frontier and social profit inefficiency can be estimated from data on outputs, inputs and externalities using Data Envelopment Analysis (DEA) or Stochastic Frontier Analysis (SFA). Although SFA has the advantage that it takes into account measurement errors and random noise, SFA has been found not to be flexible when it comes to profit decomposition [47]. Moreover, in SFA, restrictions need to be imposed a priori on the functional form representing the production technology [48]. Accordingly, this paper uses DEA, a non-parametric method that can easily accommodate multiple outputs, inputs and externalities [48]. The linear models used in the computation are presented in Supplementary Material 1. The linear models were computed using General Algebraic Modelling (GAMS).

\subsubsection{Socio-Economic Characteristics, Management Practices and Social Profit Inefficiency}

As stated earlier, we hypothesize that there is a statistical association between a set of farm-specific variables (socio-economic characteristics and management practices) and the level of social profit inefficiency and its components. To investigate this, a typical method is to produce inefficiency scores using the non-parametric DEA and then regress these scores against a set of explanatory variables to explain observed inefficiencies using a Tobit regression model [33]. However, some authors showed serious limitations with this method, as it does not consider the underlying data generation process (DGP), and serial correlation of the DEA inefficiency scores [49,50]. Considering that, in our case, inefficiency scores are derived from a production frontier, which causes serial correlation of the inefficiency scores, we follow the two-stage approach of [49], which appropriately accounts for the DGP and provides valid and consistent inferences for factors explaining inefficiency. Two alternative bootstrap procedures are proposed, i.e., the single and the double bootstrap procedures, Algorithm number 1 and Algorithm number 2 respectively [49]. In the single bootstrap procedure (Algorithm number 1), inefficiency scores are estimated in a first stage using DEA. Then, in a second stage, these scores are regressed on a set of variables using a bootstrap truncated regression model. In the 
double bootstrap procedure, on the other hand, a bootstrap is included in the first stage to produce bias-corrected estimates of the DEA inefficiency scores. In the second stage, these DEA estimates are regressed on a set of variables as in Algorithm number 1. In this study, we use Algorithm number 1. For details of the algorithm, we refer the reader to [49]. The bootstrap truncated regression model is defined as:

$$
I=a+z_{k} \beta+\varepsilon_{k}
$$

where the inefficiency scores I (NI, PTI, SI and AI) obtained in Equations (4) and (8)-(10) are regressed on the vector $z=1, \ldots V$ of farm-specific socio-economic characteristics and management practices that may have statistical association with the sustainability performance of coffee farms in Vietnam. The variables in this vector are different from the outputs, inputs, and externalities used to calculate the NI indicator. $\beta$ denotes the regression coefficients and $\varepsilon_{k}$ represents the error term with a normal distribution $N\left(0, \sigma_{\varepsilon}^{2}\right)$. Inefficiency scores are truncated between 0 and infinity, where 0 relates to the most efficient farms. The dependent variables (NI, PTI, SI and AI) reflect the level of inefficiency of coffee farms. A positive coefficient indicates that the variable is positively associated with inefficiency; hence, this variable increases the inefficiency of coffee farms.

It is worth noting that as we do not employ the double bootstrap procedure, we are not able to report bias-corrected estimates of the DEA inefficiency scores. Therefore, our inefficiency scores can be viewed as sample estimates of inefficiency. Nevertheless, even if this procedure was used, it would only yield bias-corrected technical inefficiency scores and not bias-corrected profit and allocative inefficiency scores.

\section{Data}

Data used in this study were collected between 2007 and 2009 in Chu Se District, Gia Lai province by the project 'Quality and Sustainability Improvement of Robusta Production and Trade in Gia Lai, Vietnam', funded by the Douwe Egberts Foundation and conducted by EDE Consulting. Gia Lai province is located in the Central Highlands of Vietnam. It borders to the north with Kon Tun province, to the south with Dak Lak province, to the east with Binh Dinh providence and to the west with Cambodia. The population of Gia Lai is 1.36 million, of which, approximately $80 \%$ depend on agriculture [51]. Coffee production is one of the main economic activities in the region. Gia Lai has 80,000 hectares planted in coffee and accounts for $12 \%$ of total Robusta coffee area in Vietnam [52].

In Chu Se District, Gia Lai province, 800 coffee growers voluntarily participated in the project, mainly because of their interest on improving productivity and efficiency of input use. The project provided training to these farmers, through 40-trained key farmers and 14 governmental extension staff. Apart of the training, interested farmers kept daily records on field books of frequency of activities such as fertilizing, weeding, pruning and spraying, on the use and costs of inputs such as labor, fertilizer (quantity of Nitrogen, Phosphorous and Potassium) and pesticides, and on the coffee output produced. Information on socio-economic characteristics such as the education level, age of farmer, number of household members, ethnic group and distances of the farm to the city/town center, fertilizer shop and coffee trader/factory were also collected. Key farmers gathered and reviewed the data to check for potential errors. The number of participants decreased from 739 in 2007 to 661 in 2009. Drop-out was mainly because farmers shirted to other crops (especially pepper) and because of farmers finding record keeping rather demanding. Reasons to keep record were due to the requirements by UTZ and 4C (certification bodies). Participating farmers received feedback through annual individual reports, containing detailed analysis of financial and physical performance of their farm, and 'group' reports that enabled farmers to compare themselves with their peers. The daily records of farmers were digitized by project staff to make these reports possible [51].

Out of the 661 farms in 2009, we selected 361 coffee farms to conduct this study. For these farms, data was selected from field books for the year 2009 and cover one production cycle. The remaining farms were not included in the analysis as field books were incomplete in terms of input-output information. One output (coffee beans) and four inputs (variable inputs, labor, land, and water) were 
included. Land was assumed to be a fixed input in coffee production: coffee is a perennial crop that remains fruitful for 20 to 30 years [40]. The environmental impacts of coffee production in Vietnam are mainly caused by high fertilization, inadequate use of pesticides, deforestation, and depletion of groundwater [5,53-55]. Therefore, the following negative environmental externalities were selected: greenhouse gas emissions, nitrate pollution, and pesticide toxicity. Due to data limitations, externalities related to deforestation and groundwater reduction were not included in this assessment.

Coffee farms in this sample are similar in terms of the coffee produced, i.e., Robusta, tree age, and soils conditions, but vary in intensity of input use and farm size. The average farm size planted with coffee in this sample was 1.1 hectares. According to [40], a farm with planted coffee area of 1.5 hectares or less is classified as a small farm, and a farm with planted coffee area greater than 1.5 hectares is classified a large farm. Therefore, $85 \%$ of the sampled farms could be considered small farms and $15 \%$ of the farms large farms (Table 1).

\subsection{Quantity of Outputs, Inputs, and Externalities}

The quantity of coffee beans is expressed in tons of green bean equivalents (GBE) produced in a production cycle (one year in Vietnam). The implicit quantity of variable inputs is expressed as annual aggregated expenditures on fertilizers and chemical pesticides (herbicides, insecticides, and fungicides) in 2009 US dollars (\$). Labor is measured as the total number of working days used at the farm, including both family and hired labor (a working day equals eight hours of work). Land is defined as the area utilized for coffee production, measured in hectares (ha). The quantity of water used for irrigation is expressed in cubic meters $\left(\mathrm{m}^{3}\right)$.

The negative externality greenhouse gas emissions is expressed in $\mathrm{CO}_{2}$ equivalents $\left(\mathrm{CO}_{2}\right.$-eq. $)$. Three greenhouse gasses were considered: carbon dioxide $\left(\mathrm{CO}_{2}\right)$, methane $\left(\mathrm{CH}_{4}\right)$, and nitrous oxide $\left(\mathrm{N}_{2} \mathrm{O}\right)$. For each greenhouse gas, the annual amount of gas emitted to the atmosphere was multiplied by its global warming potential over a time frame of 100 years, relative to that of $\mathrm{CO}_{2}$ [56]. These amounts were then summed to obtain the total annual amount of greenhouse gas emissions. Two sources of emissions were considered: (i) emissions that are intrinsically associated with the production of fertilizers and pesticides (embedded emissions); and (ii) $\mathrm{N}_{2} \mathrm{O}$ emissions caused by direct and indirect Nitrogen (N) emissions (see below). Emission factors of production of pesticides and fertilizers were obtained from the scientific literature [57-59].

The externality nitrate pollution captures the amount of $\mathrm{N}$ that is released to the environment in the form of nitrates $\left(\mathrm{NO}_{3}-\mathrm{N}\right)$ and is expressed in kilograms of nitrates as $\mathrm{N}\left(\mathrm{kg} \mathrm{NO}_{3}-\mathrm{N}\right)$. This externality was calculated for each coffee farm as the difference between the amount of $\mathrm{N}$ that enters the system and the amount of $\mathrm{N}$ that leaves the system, as we assumed that coffee farms are in equilibrium with respect to $\mathrm{N}$ in the system. $\mathrm{N}$ enters the system through the application of fertilizers. The amount of $\mathrm{N}$ that leaves the system includes the amount of $\mathrm{N}$ that is lost via background emissions $\left(\mathrm{N}_{2} \mathrm{O}-\mathrm{N}\right)$, fertilizer-induced and crop residue emissions $\left(\mathrm{N}_{2} \mathrm{O}-\mathrm{N}\right.$ and NO-N), $\mathrm{N}$ lost via volatilization $\left(\mathrm{NH}_{3}-\mathrm{N}\right.$ and NO-N), and $\mathrm{N}$ that is exported in the harvest material. We assumed steady-state conditions for soil organic matter: organic matter lost through mineralization is compensated by pruning, dying leaves and dying roots that are added to the soil. $\mathrm{N}$ inputs from fertilizers were estimated as the quantity of each type of fertilizer ( $\mathrm{kg}$ of synthetic and organic fertilizer) multiplied by the known (or estimated) $\mathrm{N}$ concentration per kilogram of fertilizer. $\mathrm{N}$ contents of organic material used as fertilizer are generally not measured and estimates are based on existing literature [60,61]. Nitrogen inputs from crop residues were estimated as the annual amount of crop residues ( $\mathrm{kg}$ of dry matter per year), multiplied by the average estimated $\mathrm{N}$ concentration per kilogram of dry matter ( $\% \mathrm{~N}$ per kg dry matter) [62-64]. $\mathrm{N}_{2} \mathrm{O}-\mathrm{N}$ background emissions were calculated based on the emission factor proposed by [56] for tropical climates on a per-hectare basis. Fertilizer-induced and crop-residue $\mathrm{N}$ emissions were estimated using the generic emission factors of [65], which reflect the percentage of the applied $\mathrm{N}$ that is lost via $\mathrm{N}_{2} \mathrm{O}-\mathrm{N}$ and NO-N emissions. The generic emission factors differ per type of fertilizer. The average emission factor of [65] is approximately $1 \%$ of total $\mathrm{N}$ fertilizer. This value is similar to the default 
value published by [56] and to the results of $\mathrm{N}_{2} \mathrm{O}-\mathrm{N}$ emissions found in the field by $[63,66]$ in coffee plantations in Costa Rica. N loss via volatilization was estimated using Tier II [56]. N export through the coffee harvest was estimated using yield data and figures on nutrient removal from harvesting coffee beans [55].

The externality pesticide toxicity is expressed using the environmental impact quotient (EIQ) score and was estimated using the EIQ model developed by [67] to provide an assessment of the risks involved with pesticide use. The EIQ model does not provide exact measurements of the impact of pesticide application, but allows the comparison of potential impacts from different farm management practices. The model gives an EIQ score to each active ingredient for three components: environment, farm worker and consumer. The EIQ score for the environmental component reflects the impact of the active ingredient on aquatic life, bees, birds, and beneficial insects. The EIQ score for the farm worker component reflects the impact on applicators and pickers, and the EIQ score for the consumer component reflects the impact of the pesticide active ingredient on the consumer, caused by residues in groundwater and food [68]. The total EIQ score is calculated as the average of the three components and reflects the overall toxicity of each pesticide active ingredient. To estimate the toxicity of the weed, pest, and disease control strategy of each coffee farm, the total EIQ score for each active ingredient used at each farm was multiplied by its application rate ( $\mathrm{kg}$ of active ingredient). The EIQ scores were then summed over all the active ingredients used at the farm, yielding the externality pesticide toxicity. Higher scores represent a higher potential impact of the weed, pest, and disease control strategy of a given coffee farm.

Table 1 shows the descriptive statistics for the quantities of output, inputs, and externalities. The equations, emission and conversion factors, assumptions, and calculations of the three externalities are fully detailed in Supplementary Material 2.

Table 1. Descriptive statistics for the quantities of outputs, inputs, and externalities for the year 2009.

\begin{tabular}{|c|c|c|c|c|c|c|}
\hline Symbol & Variable & Unit & Mean & Std. Dev. & Min. & Max. \\
\hline \multicolumn{7}{|l|}{ Output } \\
\hline y1 & Coffee & tons GBE & 2.9 & 1.5 & 0.4 & 9.0 \\
\hline \multicolumn{7}{|l|}{ Inputs } \\
\hline $\mathrm{x} 1$ & Labor & $\begin{array}{c}\text { working } \\
\text { days }\end{array}$ & 239.9 & 109.0 & 36.10 & 638.5 \\
\hline$x 2$ & Water & $\mathrm{m}^{3}$ & 1463.0 & 836.9 & 240.0 & 5900.0 \\
\hline $\mathrm{x} 3$ & Variable inputs & US \$ & 947.2 & 563.3 & 44.1 & 4558.8 \\
\hline$x 4$ & Land & hectares & 1.1 & 0.6 & 0.1 & 6.0 \\
\hline \multicolumn{7}{|l|}{ Externalities } \\
\hline b1 & Pesticide toxicity & EIQ & 20.8 & 51.6 & 0.0 & 457.1 \\
\hline b2 & $\mathrm{N}$ pollution & $\mathrm{kg} \mathrm{NO}-\mathrm{N}$ & 143.8 & 85.4 & 0.0 & 842.6 \\
\hline b3 & Greenhouse gas emissions & tons $\mathrm{CO}_{2}$-eq. & 4.3 & 2.4 & 0.2 & 22.0 \\
\hline
\end{tabular}

\subsection{Prices for Outputs, Inputs and Externalities}

Prices for outputs and inputs and the economic value of externalities are all expressed in 2009 US dollars (\$). If it was necessary, prices were inflated using Consumer Price Indices.

\subsubsection{Prices for Outputs and Conventional Inputs}

Observed market prices for the output and the conventional inputs were obtained from field book data. The price used for the output coffee beans is the average annual price per ton of Robusta coffee received by coffee farmers in 2009 (\$ per ton). The quantities of pesticides and fertilizers are expressed in total expenditures. As these quantities implicitly incorporate farm-specific prices, the price of the variable input was set to one. The price of labor is the daily minimum wage in Vietnam 
(\$ per working day); this implicitly assumes that the shadow price of family labor is equal to the market wage. The social profit indicator is a measure of social welfare and measures the net benefits of the farm system for society. Hence, family labor is taken as a cost in coffee production. The annual rental value of agricultural land is used as the proxy price of land (\$ per ha of agricultural land per year). The price of irrigation water in Vietnam is computed as the cost of the fuel, electricity, and labor needed to irrigate one cubic meter of water $\left(\$\right.$ per $\left.^{3}{ }^{3}\right)$.

\subsubsection{Economic Value of Externalities}

The externalities of coffee production are not traded in well-defined markets, and therefore, market price information does not exist. The economic value for the externalities were transferred from empirical studies in published literature and adjusted to the Vietnamese context using the ratio of GDP per capita of Vietnam to the average GDP per capita of the country, where the estimation was made, expressed in purchasing power parities (PPP). This assumes that the willingness to pay (WTP) to avoid or to mitigate the damages is proportional to the per capita income of each country [69] and is locally determined.

We used the mean economic value for greenhouse gas emissions reported by [21]. In this study, the economic value per ton of $\mathrm{CO}_{2}$-eq. was calculated based on a review of values found in existing literature sources. These values reflect the societal, economic and ecological costs of emitting a unit of $\mathrm{CO}_{2}$ to the atmosphere. Costs are associated with parasitic and vector bone diseases, sea-level rise, climate instabilities, decreased water availability, droughts and biodiversity loss, among others [21].

For the economic value of the externality nitrate pollution, we relied on the study of [70]. This study provides a comprehensive assessment of the external costs of different $\mathrm{N}$ flows for the EU27 in the year 2008, among them, the health-related damages and the ecosystem damages per unit of $\mathrm{N}$ leached to the environment. The per capita income in Vietnam is lower than the per capita income of European countries. Therefore, we assumed that Vietnam's WTP to reduce human health- and ecosystem-related problems is lower compared to the European countries. Accordingly, we used the lower bound of the external costs reported by [70], adjusted to the Vietnamese context using the ratio of the GDP per capita, expressed in purchasing power parities (PPP).

In the case of the externality pesticide toxicity, the economic value of an EIQ was estimated using the pesticide environmental accounting (PEA) tool developed by [71], combined with the approach of [21]. The PEA tool estimates an economic value per unit of application of an average pesticide active ingredient, by combining the EIQ method and the base values for external pesticides costs in UK, USA and Germany reported by [72]. The PEA tool also enables the adjustment of the economic value per unit of application of an average pesticide active ingredient to different countries using the GDP per capita of a country relative to the average weighted GDP per capita of the UK, USA and Germany [71]. The description of the calculation of the externality pesticide toxicity is fully detailed in Supplementary Material 2.

Table 2 provides the descriptive statistics for the farm-specific (shadow) prices of outputs, inputs, and externalities.

Table 2. Descriptive statistics for prices of outputs, inputs, and externalities in 2009 US dollars (\$).

\begin{tabular}{cccc}
\hline Symbol & Variable & Unit & Mean \\
\hline Output & & & \\
p1 & Coffee & \$/ton GBE & 1764.7 \\
\hline Inputs & & & \\
w1 & Labor & W/working days & 4.1 \\
w2 & Water & $\$ / \mathrm{m}^{3}$ & 0.1 \\
w3 & Variable inputs & L/hectare per year & $1.0 \mathrm{a}$ \\
w4 & Land & & \\
\hline
\end{tabular}


Table 2. Cont.

\begin{tabular}{cccc}
\hline Symbol & Variable & Unit & Mean \\
\hline Externalities & & & \\
r1 & Pesticide toxicity & $\$ / \mathrm{EIQ}$ & 0.15 \\
r2 & N pollution & $\$ / \mathrm{kg} \mathrm{NO}_{3}-\mathrm{N}$ & 2.0 \\
r3 & Greenhouse gas emissions & $\$ /$ ton CO $\mathrm{CO}_{2}$-eq. & 19.0 \\
\hline
\end{tabular}

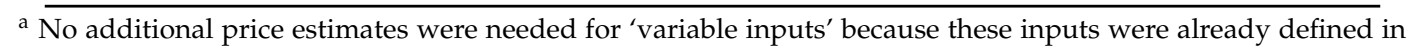
monetary terms.

\subsection{Determinants of Nerlovian Social Profit Inefficiency}

In the efficiency literature, farm inefficiencies relative to the best-practice frontier are commonly attributed to socio-economic characteristics of farm households and to improper farm management practices [38-40,73-78]. We selected eleven socio-economic and farm management variables (Table 3) as potential determinants that could be statistically associated with NI and its components. The socio-economic variables were: (i) distance of the farm to the fertilizer shop (measured in kilometers); (ii) distance of the farm to the closest city/town center (measured in kilometers); (iii) distance of the farm to the closest coffee trader/factory (measured in kilometers); (iv) family members (measured as the number of members); (v) two variables representing the education of the husband and the education of the wife (each measured as a categorical variable, where 0 reflects five years of primary education, 1 reflects an additional 4 years of intermediate education, and 2 reflects an additional 3 years of secondary education); and (vi) ethnic group (binary variable, where 0 refers to the ethnic group Kinh, which is the major group in Vietnam, and 1 to the ethnic group JoRai). Five explanatory variables reflecting farm management practices were included: the frequency of (vii) pruning, (viii) fertilization, (ix) weeding, and (x) pest and disease control (each measured as the number of times that the activity is performed in one production cycle), and (xi) the share of hired labor in total labor (measured as percentage). Only coffee farms with complete information for the selected variables were used in the bootstrap truncated regression: 302 out of the 361 coffee farms in the sample.

Table 3. Descriptive statistics for socio-economic characteristics and management practices (302 DMUs).

\begin{tabular}{cccccc}
\hline Variable & Unit & Mean & Std. Dev. & Min. & Max. \\
\hline Continuous variables & & & & & \\
\hline Distance to fertilizer shop & kilometers & 2.3 & 2.2 & 0.1 & 12.0 \\
Distance to city/town center & kilometers & 36.4 & 6.8 & 2.0 & 53.0 \\
Distance to coffee factory/trader & kilometers & 3.3 & 3.0 & 0.0 & 15.0 \\
Family members & number & 4.0 & 2.0 & 1.0 & 9.0 \\
Hired labor & \% of total labor & 39.3 & 23.8 & 0.0 & 94.6 \\
Pruning & frequency & 6.4 & 2.6 & 0.0 & 11.0 \\
Spraying & frequency & 0.4 & 0.6 & 0.0 & 2.0 \\
Fertilizing & frequency & 3.9 & 1.2 & 1.0 & 7.0 \\
Weeding & frequency & 4.8 & 1.6 & 0.0 & 9.0 \\
\hline Categorical variables & & & & & \\
\hline Education husband & & 1.1 & 0.6 & 0.0 & 2.0 \\
Education woman & & 1.0 & 0.6 & 0.0 & 2.0 \\
Ethnic group & & 0.1 & 0.3 & 0.0 & 1.0 \\
\hline
\end{tabular}

Education $=0$ reflects primary education, 1 reflects intermediate education, and 2 reflects secondary education); Ethnic group $=0$ refers to the ethnic group Kinh and 1 to the ethnic group JoRai.

We hypothesized that the inefficiency scores (NI, PTI, SI, and AI) are positively associated with the variables related to distance, spraying, and ethnic group, and that the inefficiency scores are negatively 
associated with family members, hired labor, pruning, fertilizing and weeding. We expect a mixed effect for the variable education. Our hypotheses are based on the following assumptions:

- The farther away the farm is from the fertilizer shop, town/city center, or coffee factory/trader, the more difficult or costly it is for farmers to commercialize products and to have access to inputs, credit and extension services, which should, therefore, lead to increased inefficiency scores. For example, in the study of [40] in coffee farms in Vietnam and [76] in coffee farms in Cameroon, it was found that farmers with better access to credits and markets have overall lower production costs and lower inefficiency scores;

- The Kinh ethnic group has higher profit maximization behavior in comparison to the JoRai group [14]. In addition to being the major group in Vietnam, this group often farms areas more favorable for coffee production [79] and is more likely to have better access to extension services, education and technical information [39]. Therefore we expect Kinh farmers to have lower inefficiency scores;

- $\quad$ Coffee growing is labor intensive [7] and therefore families with more members have more potential labor (time) to allocate to activities such as harvesting, pruning and weeding, which are mostly done by manual labor [7];

- $\quad$ Hired labor is better qualified to perform (particular) field activities [80]; hence, a more efficient use of labor is achieved with hired labor, which should lead to lower inefficiency scores. For example, in the study of [40], it was found that cost inefficiency in coffee production in Vietnam is associated with lower levels of hired labor;

- More frequent pruning, fertilizing, and weeding leads to better crop productivity, because the availability and uptake of nutrients is higher, which in turn leads to more efficient use of inputs [55];

- The larger the number of spraying events, the higher the inefficiency scores of coffee farms. It has been demonstrated that small-scale farmers in different types of farming systems overuse pesticides. Reasons include risk-adversity, limited or lack of knowledge on how to use pesticides and non-proper equipment [81]. Over-use of pesticides implies more labor allocated to this activity and higher production costs;

- $\quad$ For education, a mixed effect can be expected. Higher education levels can lead to lower inefficiency scores because more years of schooling may indicate higher managerial skills, specific professional training, better access to information and adequate farm planning [34,74]. Empirical evidence of this effect was found by [7] in coffee farms in Vietnam, by [76] in coffee farms in Cameroon, by [39] in rice in Vietnam, by [77] in oil palm plantations in Indonesia and, by [78] in maize in Ethiopia. On the other hand, higher education levels have also been found to have a positive and significant effect on farm inefficiencies. Examples include [74] in poultry production in Nigeria and [40] in coffee production in Vietnam. The positive effect of education on farm inefficiencies may indicate that farmers with more years of schooling may have better off-farm options and less time for supervision of their farms.

\section{Results}

\subsection{Composition of the Nerlovian Social Profit Inefficiency}

Table 4 presents summary statistics for the observed social profits, the computed NI scores, and the decomposition into the PTI, SI, and AI components. 
Table 4. Mean values for the total sample and mean values for each quartile (Q1-Q4) for the observed social profit and NI, PTI, SI, and AI scores. The Q1 group represents the farms with the lowest inefficiency scores and the $\mathrm{Q} 4$ represents the farms with the highest inefficiency scores.

\begin{tabular}{ccccccc}
\hline Variable & Mean & Std. Dev. & Q1 & Q2 & Q3 & Q4 \\
\hline Observed social profit & 2279.3 & 1829.7 & 3949.6 & 2334.4 & 1877.8 & 959.7 \\
NI & 0.84 & 0.48 & 0.36 & 0.63 & 0.89 & 1.47 \\
PTI & 0.26 & 0.15 & 0.14 & 0.22 & 0.31 & 0.38 \\
SI & 0.02 & 0.05 & 0.01 & 0.02 & 0.03 & 0.03 \\
AI & 0.55 & 0.40 & 0.21 & 0.39 & 0.56 & 1.06 \\
\hline
\end{tabular}

$P T I=$ pure technical inefficiency; $S I=$ Scale inefficiency; $A I=$ Allocative inefficiency. $N I=$ Nerlovian social profit inefficiency $=P T I+S I+A I$.

The average observed social profit for our sample of coffee farms in Vietnam is approximately $\$ 2300$. The distribution of the observed social profits shows that $95 \%$ of the sampled coffee farms obtained a positive social profit. This indicates that, on average, the revenues of coffee sales cover the costs of inputs used in coffee production as well as the social costs associated with the environmental externalities. However, our results show a large potential for improvement in social profit. NI scores for our sample range between 0.00 and 4.76, with mean values per quartile varying between 0.36 and 1.47 (Table 4) (each quartile consists of $25 \%$ of farms. The first quartile (Q1) represents the farms with the lowest NI scores and the fourth quartile (Q4) represents the farms with the highest NI scores). The NI indicator equals zero when the observed farm is located on the production frontier. This means that, on average, the farms in our sample could increase their social profit by almost three times the current social profit levels, that is, $84 \%$ or more of the value of the NI denominator (normalization of the NI indicator).

The decomposition of the NI scores into the three components highlights the following findings: (i) up to $66 \%$ of the social profit inefficiency can be attributed to allocative inefficiency (allocative inefficiency accounts for 0.55 of the value of the NI denominator, which is 0.84 ). This component is the main source of social profit inefficiency. Hence, a significant improvement in the relative sustainability performance could be achieved by choosing a better combination of inputs and pollution levels in coffee production at given (shadow) prices. (ii) Pure technical inefficiency, with $26 \%$, is the second source of social profit inefficiency. Although we did not find any study that used a DDF to measure the pure technical inefficiency of coffee farms in Vietnam, our results are similar to those found by [82], who estimated an average inefficiency level of about $18 \%$ in coffee farming systems in Vietnam using an input distance function. (iii) The loss of social profit due to scale inefficiency is small in our sample, suggesting that farmers generally operate close to the optimal size and therefore there is little potential to improve the efficiency of production by adjusting the scale at which they operate.

Table 5 presents the results of the decomposition of NI scores to identify the output-specific, input-specific, and externality-specific contributions. The results of this decomposition highlight the following findings. (i) The main source of NI is caused by the under-production of coffee; the production of most coffee farms is low compared to the maximum possible production level. (ii) Inputs in coffee production are, on average, under-used in our sample. The use of variable inputs can be increased to reach optimum coffee production levels. However, we cannot indicate which variable input (fertilizers or pesticides) could contribute the most to the increase in production. (iii) The quantities of externalities produced are generally close to the optimum levels. 
Table 5. Mean values for the total sample and each quartile (Q1-Q4) for the decomposition of NI scores into output-specific, input-specific, and externality-specific inefficiencies. The Q1 group represents the farms with the lowest NI scores and the Q4 represents the farms with the highest NI scores.

\begin{tabular}{cccccc}
\hline & Mean & Q1 & Q2 & Q3 & Q4 \\
\hline Coffee & 1.13 & 0.54 & 0.86 & 1.17 & 1.97 \\
Labor & -0.16 & -0.09 & -0.13 & -0.16 & -0.27 \\
Water & -0.01 & -0.01 & -0.01 & -0.01 & -0.02 \\
Variable inputs & -0.10 & -0.06 & -0.07 & -0.09 & -0.17 \\
Pesticide toxicity & 0.00 & 0.00 & 0.00 & 0.00 & 0.00 \\
N pollution & -0.02 & -0.01 & -0.01 & -0.01 & -0.03 \\
Greenhouse gas emissions & -0.01 & 0.00 & 0.00 & -0.01 & -0.01 \\
NI & 0.84 & 0.36 & 0.63 & 0.89 & 1.47
\end{tabular}

A positive (negative) sign for the output indicates that it is under-produced (over-produced). A positive (negative) sign for the inputs indicate that they are over-used (under-used). A positive (negative) sign for the externalities indicates that these are produced above (below) the optimum pollution level. The land input is not included, as it is taken as fixed factor of production.

As the sustainability of coffee production in Vietnam depends on the world market price of coffee and on the local prices of labor, variable inputs, and water, we conducted a sensitivity analysis to explore the effect of changes in these prices on the sustainability performance of coffee production in Vietnam (Table 6). A further reason for the sensitivity analysis is the fact that we underestimated the price of water. The price of water, expressed as the cost of the fuel, electricity, and labor needed to irrigate one cubic meter of water, does not internalize the external costs that result from reduced groundwater availability, changes in recharge and discharge patterns, waterlogging, salinity, and loss of biodiversity. In the sensitivity analysis, we analyzed the sensitivity of the results for three price changes: (i) a reduction in the unit price of coffee of $15 \%$, (ii) an increase in the unit price of labor of $40 \%$, and (iii) a one dollar increase in the unit price of water.

Table 6. Maximum attainable and observed values for social profits and quantities of outputs, inputs, and externalities for the three price changes. Change 1: reduction of coffee price by $15 \%$; Change 2 : increase in the unit price of labor by $40 \%$; Change 3: a one dollar increase in the unit price of water.

\begin{tabular}{|c|c|c|c|c|c|c|}
\hline Variable & Unit & & Current & Change 1 & Change 2 & Change 3 \\
\hline \multirow[b]{2}{*}{ Social Profit } & \multirow[b]{2}{*}{$\$$} & Max. & 7475.3 & 5500.0 & 6711.4 & 5368.7 \\
\hline & & Obs. ${ }^{a}$ & 2128.9 & 1332.5 & 1761.0 & 732.6 \\
\hline \multicolumn{7}{|l|}{ Outputs } \\
\hline \multirow{2}{*}{ Coffee } & \multirow{2}{*}{ tons GBE } & Max. & 6.8 & 6.3 & 6.5 & 5.5 \\
\hline & & Obs. & 2.6 & 2.6 & 2.6 & 2.6 \\
\hline \multicolumn{7}{|l|}{ Inputs } \\
\hline \multirow[b]{2}{*}{ Labor } & \multirow{2}{*}{ working days } & Max. & 482.0 & 410.4 & 433.6 & 282.0 \\
\hline & & Obs. & 226.6 & 226.6 & 226.6 & 226.6 \\
\hline \multirow{2}{*}{ Water } & \multirow{2}{*}{$\mathrm{m}^{3}$} & Max. & 2200.0 & 2030.5 & 2085.3 & 1723.0 \\
\hline & & Obs. & 1396.4 & 1396.4 & 1396.4 & 1396.4 \\
\hline \multirow{2}{*}{ Variable inputs } & \multirow{2}{*}{$\$$} & Max. & 1465.8 & 1227.5 & 1304.6 & 799.9 \\
\hline & & Obs. & 877.2 & 877.2 & 877.2 & 877.2 \\
\hline \multicolumn{7}{|l|}{ Externalities } \\
\hline \multirow{2}{*}{ Pesticide toxicity } & \multirow{2}{*}{ EIQ } & Max. & 52.2 & 37.5 & 42.2 & 11.4 \\
\hline & & Obs. & 17.6 & 17.6 & 17.6 & 17.6 \\
\hline \multirow{2}{*}{$\mathrm{N}$ pollution } & \multirow{2}{*}{$\mathrm{kg} \mathrm{NO}_{3}-\mathrm{N}$} & Max. & 192.0 & 151.0 & 164.3 & 77.3 \\
\hline & & Obs. & 142.2 & 142.2 & 142.2 & 142.2 \\
\hline \multirow{2}{*}{ Greenhouse gas emissions } & \multirow{2}{*}{ tons $\mathrm{CO}_{2}$-eq. } & Max. & 6.0 & 5.0 & 5.3 & 3.3 \\
\hline & & Obs. & 4.0 & 4.0 & 4.0 & 4.0 \\
\hline
\end{tabular}

a. Under the three price changes, the revenues and expenditures change. Therefore, the term "observed social profit", in this case, refers to the social profit that would be obtained under each price change. The term "observed" for the output, inputs and externalities refers to the actual quantities. 
The results of the sensitivity analysis show that the maximum attainable social profits decreased by $26 \%, 10 \%$, and $28 \%$, and the observed social profits by $37 \%, 17 \%$, and $66 \%$ for the price change 1,2 , and 3, respectively. Equally importantly, the distribution of the observed social profits shows that the percentage of farms in the sample that obtained a positive social profit declined from $95 \%$ to $88 \%$ under price change 1,92\% under price change 2, and 69\% under price change 3 . Maximum attainable social profit and observed social profit are both lower in the three price changes because fewer economic resources are available for production (Table 6). To maximize social profits, farmers have to reduce their expenditures by allocating fewer economic resources, especially for those inputs for which the price has increased, which in turn would imply a lower production of coffee beans and a lower gross income.

\subsection{Determinants of Nerlovian Social Profit Inefficiency}

After the calculation of NI and its components PTI, SI, and AI, the next step was to explore the statistical association of socio-economic characteristics and management practices and the sustainability performance of the farms. Table 7 presents the coefficient estimates and confidence intervals for the bootstrap truncated regression of the NI scores and the PTI, SI, and AI components. The dependent variables are framed in terms of inefficiency, so a positive (negative) coefficient indicates greater (lower) inefficiency. Most of the explanatory variables were found to be highly statistically associated with farm-specific NI scores (Table 7), and are mainly associated with allocative inefficiencies. Exceptions are the variables distance to the fertilizer shop, family members and weeding and the categorical variables for education. None of these variables has a statistically significant association with social profit inefficiency or its components.

Distance to city/town center: The positive effect on farm-specific NI scores and the AI component shows that distance is associated with a higher inefficiency in social profit; this effect is attributable to allocative inefficiency. This result suggests that farmers farther away from city or town centers may have less access to credit, which may hamper an efficient allocation of inputs [83]. Distance of the farm to the city or town center could also increase the costs of bringing inputs to the farm and hiring labor. Furthermore, extension services may have more difficulty to reach remote areas of Vietnam. A study by [83] stated that, although the Vietnamese government has attempted to improve the access of farmers to extension services, poor infrastructure still reduces access for those farmers located further from centers.

Distance to coffee factory/traders: The positive values for NI and AI indicate that greater distance to regional traders might be associated with a higher social profit inefficiency; this effect is mainly due to an inefficient allocation of resources $(A I)$. Most farmers in Vietnam sell their coffee production to regional traders or deliver it themselves to coffee processing factories [83]. Farmers located farther away from traders need to allocate more economic resources, i.e., labor and time, to the transportation of coffee. Hence, a larger distance could lead to sub-optimal allocation of inputs and outputs.

Hired labor: NI, PTI, and AI all have negative coefficients associated with the share of hired labor. This shows that greater use of hired labor can be a factor that reduces the pure technical inefficiency and allocative inefficiency of farms, thereby leading to lower social profit inefficiency. Hired labor is generally more qualified to perform specialized tasks, compared with family labor $[80,84]$. Coffee plantations with higher productivity levels tend to use labor more efficiently, as more time is spent on picking from heavily loaded trees and relatively less time is needed to find the cherries and to walk from tree to tree. Therefore, a higher use of specialized hired labor may be associated with more productive farms. More efficient use of labor reduces labor costs and increases the profitability of the coffee farm. 
Table 7. Effect of socio-economic characteristics and management practices on the NI scores and the PTI and AI components. Effects on farm-specific SI scores were excluded, as differences between farms were negligible.

\begin{tabular}{|c|c|c|c|c|c|c|c|c|c|}
\hline \multirow[b]{2}{*}{ Variable } & \multicolumn{3}{|c|}{ Nerlovian Social Profit Inefficiency (NI) } & \multicolumn{3}{|c|}{ Pure Technical Inefficiency (PTI) } & \multicolumn{3}{|c|}{ Allocative Inefficiency (AI) } \\
\hline & $\begin{array}{l}\text { Estimated } \\
\text { Parameter }\end{array}$ & $\begin{array}{l}\text { Upper } \\
\text { Bound }\end{array}$ & $\begin{array}{l}\text { Lower } \\
\text { Bound }\end{array}$ & $\begin{array}{l}\text { Estimated } \\
\text { Parameter }\end{array}$ & $\begin{array}{l}\text { Upper } \\
\text { Bound }\end{array}$ & $\begin{array}{l}\text { Lower } \\
\text { Bound }\end{array}$ & $\begin{array}{l}\text { Estimated } \\
\text { Parameter }\end{array}$ & $\begin{array}{l}\text { Upper } \\
\text { Bound }\end{array}$ & $\begin{array}{l}\text { Lower } \\
\text { Bound }\end{array}$ \\
\hline Distance fertilizer shop & 0.000 & 0.034 & -0.034 & -0.005 & 0.004 & -0.014 & 0.000 & 0.036 & -0.037 \\
\hline Distance to city/town center & 0.016 & 0.031 & 0.003 & 0.003 & 0.007 & 0.000 & 0.018 & 0.036 & 0.004 \\
\hline Distance to factory/traders & 0.023 & 0.044 & 0.002 & -0.001 & 0.005 & -0.007 & 0.032 & 0.055 & 0.010 \\
\hline Family members & -0.027 & 0.018 & -0.069 & -0.006 & 0.006 & -0.017 & -0.034 & 0.012 & -0.080 \\
\hline Education man & -0.024 & 0.105 & -0.153 & -0.023 & 0.011 & -0.058 & -0.005 & 0.133 & -0.145 \\
\hline Education woman & 0.030 & 0.151 & -0.095 & 0.008 & 0.040 & -0.024 & 0.032 & 0.170 & -0.103 \\
\hline Hired labour & -0.006 & -0.003 & -0.010 & -0.001 & -0.001 & -0.002 & -0.007 & -0.004 & -0.011 \\
\hline Ethnic group & -0.341 & -0.039 & -0.675 & -0.109 & -0.029 & -0.199 & -0.337 & -0.015 & -0.691 \\
\hline Pruning & -0.035 & -0.002 & -0.068 & 0.005 & 0.013 & -0.004 & -0.059 & -0.023 & -0.098 \\
\hline Spraying & 0.124 & 0.230 & 0.015 & 0.042 & 0.069 & 0.013 & 0.129 & 0.251 & 0.012 \\
\hline Fertilizing & -0.019 & 0.036 & -0.081 & 0.022 & 0.036 & 0.005 & -0.081 & -0.024 & -0.150 \\
\hline Weeding & 0.018 & 0.063 & -0.029 & 0.011 & 0.022 & -0.002 & -0.004 & 0.042 & -0.055 \\
\hline Constant & 0.614 & 1.211 & -0.053 & 0.081 & 0.235 & -0.088 & 0.516 & 1.154 & -0.210 \\
\hline Sigma & 0.463 & 0.516 & 0.410 & 0.129 & 0.142 & 0.116 & 0.404 & 0.469 & 0.343 \\
\hline
\end{tabular}

$95 \%$ confidence intervals for significant variables are marked in bold type. A positive estimate parameter indicates greater inefficiency. 
Ethnic group: The variable ethnic group has a negative effect on the NI, PTI, and AI scores. This indicates that the minority group JoRai can be associated with a lower pure technical inefficiency and a better allocation of resources than the other ethnic group. This finding is contrary to our expectations, as minority groups, such as the JoRai, often farm areas that are less favorable for coffee production and sometimes cannot afford to purchase inputs, such as fertilizers and water [79,83]. One reason for the lower social profit inefficiency could be the higher dependency of the JoRai on coffee production for their livelihood. Consequently, the members of this group may undertake key farm activities, such as pruning and fertilizing, with more care. In contrast, the Kinh people tend to have relatively more diversified sources of income $[14,83]$. Thus, less effort and family labor may be allocated to coffee production.

Pruning: The negative coefficient for NI and AI shows that the frequency of pruning activities is negatively associated with social profit inefficiency, consistent with our expectations. More frequent pruning improves ventilation and increases penetration of sunlight into the canopy, avoids excessive competition for nutrients and water between the cherries, and reduces non-productive structures of trees $[8,55]$. Additionally, a part of the nutrients taken up by coffee trees is available to coffee plants in following years, by placing the pruning residues into soils [60]. Coffee trees with better structural and physiological characteristics have higher yields and therefore reduce the social profit inefficiency of coffee farms.

Spraying: NI, PTI, and AI are all positively associated with spraying, meaning that more applications of chemical pesticides increase the social profit inefficiency, and the technical and allocative inefficiencies. The most likely reason is that the application of pesticides is not effective, especially for control of fungal diseases and insect pests, possibly due to improper use of pesticides and incorrect timing of spraying. Coffee plantations with higher incidences of diseases and pests may also require more frequent use of pesticides to maintain productivity. However, as most farms in the sample are operating under similar agro-ecological conditions, there is little difference in the intensity of diseases and pests [85].

Fertilizing: The coefficient for the effect of fertilizing on farm-specific NI scores is statistically not significant. However, coefficients for the effect of fertilizing on AI and PTI scores indicate that these are statistically associated with inefficiency in social profit. This effect is complex, however, as increasing the frequency of fertilizer application might be linked with an increase of the PTI component, but might reduce the $A I$ component. An explanation for the positive effect on PTI is that more frequent application of fertilizers implies higher input use per unit of output, and therefore increased pure technical inefficiency. An explanation for the negative effect on $A I$ is suggested by the results of a previous study on fertilizer application $[8,10]$. These studies showed that an adequate application of fertilizers during periods of greatest crop demand, in smaller and more frequent applications, was positively related to reduced nutrient losses and improvements in yields. Hence, a higher allocation of labor for this activity is expected to decrease the allocative inefficiency, and thereby the social profit inefficiency.

\section{Discussion}

The social profit inefficiency score that we have used entails a weak sustainability approach [24]. We believe this practical approach is justified for this specific problem but the weak sustainability assumption must be carefully evaluated if and when this approach is used in other production environments or when different inputs, outputs and/or externalities are considered.

Deforestation and groundwater depletion are important aspects of sustainability of coffee farming in Vietnam [5,7,9,53-55]. Most coffee farms are groundwater irrigated [86]. It is an economic concern that the cost of groundwater irrigation increases as the groundwater level decreases. It is an environmental concern that groundwater depletion takes place at all [87]. In addition, the application of fertilizer and yield of coffee depend to some extent on the timing and volume of irrigation [6]. In this 
paper, we were not able to deal with these issues because of a lack of data. Our analysis would be usefully extended by taking these issues into account.

The results show that the majority of the externalities are below optimal level, indicating that the external costs (greenhouse gas emissions, nitrate pollution and pesticide toxicity) could increase and still yield a lower social profit inefficiency. This outcome is based on the model assumptions. Further development and use of the social profit inefficiency indicator should incorporate critical loads, targets and restrictions (maximum restrictions) for the use of certain inputs, and for the production of externalities.

The findings from this research cannot be directly extrapolated to the entire coffee in Vietnam as the outcomes of our model pertain to the sample (see sub Section 2.2.2). Nevertheless, the results of this study can help farmers, researchers, and policy makers identify opportunities where the sustainability performance of coffee farms in Vietnam can be improved. At the farm level, the inefficiency in social profit may be greatly reduced by decreasing the inefficient use of nutrients. An optimal use of nutrients would not only positively affect coffee yields, but would also reduce greenhouse gas emissions, reduce the emission of nitrates into soils and water bodies, and lead to a lower need for the application of pesticides. Greater use of pesticide inputs is caused, in some cases, by nutrient deficiencies or over-fertilization of coffee plantations [8]. Corrective actions to reach an optimal use of fertilizer inputs would reduce expenditures and the amount of labor required to perform activities, such as weeding and spraying. Some of the labor used to perform these activities could then be allocated to other activities, such as pruning, which are negatively associated with social profit inefficiency. Moreover, policies should stimulate proper timing and frequency of spraying through optimal extension services. In Vietnam, it is common that farmers keep applying pesticides in a calendar pattern rather than based on signs of pest outbreak.

At the regional level, we recommend connecting remote areas with extension services and markets. It is expected to: (i) help integrate the coffee chain (producers, traders, and processing companies), (ii) increase the bargaining power of farmers (access to information on coffee prices, traders, and new products and technologies) and, (iii) increase the access of farmers to credit due to improved risk profile.

We also recommend performing an in-depth study on the management of coffee farms by the JoRai ethnic group. These farmers were found to be less inefficient in terms of social profit. The results of the study can be used to identify best management practices; extension services can then disseminate this information and stimulate the adoption of best management practices on more inefficient farms.

Further research should identify additional socio-economic characteristics and management practices of farms (e.g., timing and technology used) that may influence the sustainability performance of coffee farms in Vietnam.

At the methodological level, our approach assumes that socio-economic and farm management practices influence inefficiency of coffee farms. However, it does not allow for the possibility that these characteristics and practices affect the production possibilities [88]. Therefore, future research could also test whether the second-stage regression is supported by the data [88].

Finally, it is worth noting that the variation in farm-level externalities and the variation in the frequency of farm management practices in this study might have some measurement error. This could occur as our sample is a snapshot of coffee farms in a single year and it did not consider what happened in previous years. Thus, for example, it is unlikely that all farms are in the same stage of pruning of their plants, which in turn could affect the nutrient needs of the coffee plantations. The same type of measurement error could emerge with pesticides. In our study, the same pesticide is presumed to have the same externality across all coffee farms, regardless of when it was applied or how it was applied. Therefore, we highly recommend a multiple-year sustainability assessment, as well as the inclusion of other variables related to the farm management practices, such as timing and technology used, to improve the conclusions that were drawn from this assessment. 


\section{Conclusions}

In conclusion, this paper compared the sustainability performance of a sample of coffee farms in Vietnam using the Nerlovian social profit inefficiency (NI) indicator. Furthermore, this study identified the socio-economic characteristics and management practices that affect social profit inefficiency. The results show that farms, on average, could improve their social profits by almost three times the current social profit levels ( $84 \%$ of the value of the NI denominator). This suggests a large potential for performance improvements. The main source of $N I$ is the allocative inefficiency ( $55 \%$ of the value of the NI denominator), rather than pure technical inefficiency or scale inefficiency. The determination of variable-specific contributions to NI provides evidence of the sources of inefficiency. The comparison between the actual and optimal quantities of each specific output, input, and externality reveals that the low level of coffee production and the under-utilization of inputs, particularly labor and variable inputs, are the main drivers of inefficiency. Most coffee farms have optimum pollution levels, given the economic value of externalities.

The assessment of the external determinants of NI shows that most of the selected variables (socio-economic characteristics and management practices) have statistically association with NI and its components. Farm-specific NI scores are positively associated with the variables distance to city/town center, distance to traders and spraying. Farm-specific NI scores are negatively associated with the following variables: hired labor, ethnic group, pruning, and fertilizing. Corrective actions to ensure the efficient use of inputs and the correct timing and frequency of farm management activities would reduce social profit inefficiency for most of our coffee farms.

Although our study focused on assessing the relative sustainability performance of coffee production at the farm level, this can be extended to include other stages throughout the coffee chain. Future development of this sustainability assessment approach could provide a decision support tool that can be used to translate the concept of sustainability into concrete management actions, thereby helping to maximize the total net benefits to society of food production.

Supplementary Materials: The following are available online at http:/ / www.mdpi.com/2071-1050/10/11/4227/ s1.

Author Contributions: D.G-C. conceived the original idea of the work, conducted the literature review, and the formal analysis, and wrote the manuscript. F.K.v.E. M.P.M.M, D.M.J and A.G.J.M.O.L. initiated the theoretical dialogue, revised the manuscript, provided critical contributions to the development of the manuscript, and contributed in the writing. D.M.J. also contributed data on coffee farm in Vietnam.

Funding: This research was funded by the Ministry of Economic Affairs, the Netherlands, project "Total Factor Productivity indexing of sustainability". The APC was partially funded by Wageningen University \& Research.

Conflicts of Interest: The authors declare that they have no conflict of interest.

\section{References}

1. International Institute for Sustainable Development. Available online: http://ssrn.com/abstract=1338582 (accessed on 12 January 2016).

2. Reinecke, J.; Manning, S.; von Hagen, O. The emergence of a standards market: Multiplicity of sustainability standards in the global coffee industry. Organ. Stud. 2012, 33, 791-814. [CrossRef]

3. Nguyen, T.V.; Nguyen, N.C.; Bosch, O.J.H. Contribution of the systems thinking approach to reduce production cost and improve the quality of Vietnamese coffee. Int. J. Mark. Bus. Syst. 2015, 1, 53-69. [CrossRef]

4. The Observatory of Economic Complexity. What Does Vietnam Export? Available online: http://atlas. media.mit.edu/en/visualize/tree_map/hs92/export/vnm/all/show/2013/ (accessed on 13 January 2016).

5. D'haeze, D.; Deckers, J.; Raes, D.; Phong, T.A.; Loi, H.V. Environmental and socio-economic impacts of institutional reforms on the agricultural sector of Vietnam: Land suitability assessment for Robusta coffee in the Dak Gan region. Agric. Ecosyst. Environ. 2005, 105, 59-76. [CrossRef]

6. Amarasinghe, U.A.; Hoanh, C.T.; D'haeze, D.; Hung, T.Q. Toward sustainable coffee production in Vietnam: More coffee with less water. Agric. Syst. 2015, 136, 96-105. [CrossRef] 
7. Luong, Q.V.; Tauer, L.W. A real options analysis of coffee planting in Vietnam. Agric. Econ. 2006, 35, 49-57. [CrossRef]

8. Kuit, M.; Jansen, D.M.; Van Thiet, N. Coffee handbook: Manual for Arabica cultivation. Vietnam. Tan Lam Agricultural Product Joint Stock Company, 2004. Available online: https:/ /bootcoffee.com/wp-content/ uploads/2015/04/manual-for-arabica-cultivation-vs.pdf (accessed on 27 January 2016).

9. Van Loi, H.; Thich, H.Q. Support to Rolling out Sustainable Coffee Initiatives in Dak Lak Province. Baseline Study; E.D.E. Consulting and GTZ: Sheridan, WY, USA, 2007.

10. Tilman, D.; Cassman, K.G.; Matson, P.A.; Naylor, R.; Polasky, S. Agricultural sustainability and intensive production practices. Nature 2002, 418, 671-677. [CrossRef] [PubMed]

11. Garcia, A.F.; Shively, G.E. How might shadow price restrictions reduce technical efficiency? Evidence from a restricted DEA analysis of coffee farms in Vietnam. J. Agric. Econ. 2011, 62, 47-58. [CrossRef]

12. Lan, C.; Wintgens, J. Major pests of coffee in the Asia-Pacific Region. In Coffee: Growing, Processing, Sustainable Production. A Guidebook for Growers, Processors, Traders and Researchers; Wintgens, J., Ed.; Wiley-VCH: Weinheim, Germany, 2005; pp. 463-477, ISBN 9783527322862.

13. Carr, M. The water relations and irrigation requirements of coffee. Exp. Agric. 2001, 37, 1-36. [CrossRef]

14. Tran, N.A. Measuring the Efficiency of Coffee Producers in Vietnam: Do Outliers Matter? Master's Thesis, Purdue University, West Lafayette, IN, USA, May 2007.

15. Smith, C.S.; McDonald, G.T. Assessing the sustainability of agriculture at the planning stage. J. Environ. Manag. 1998, 52, 15-37. [CrossRef]

16. Gerbens-Leenes, P.W.; Moll, H.C.; Schoot Uiterkamp, A.J.M. Design and development of a measuring method for environmental sustainability in food production systems. Ecol. Econ. 2003, 46, 231-248. [CrossRef]

17. Kusiima, J.M.; Powers, S.E. Monetary value of the environmental and health externalities associated with production of ethanol from biomass feedstocks. Energy Policy 2010, 38, 2785-2796. [CrossRef]

18. Atkinson, G. Measuring corporate sustainability. J. Environ. Plann. Man. 2000, 43, 235-252. [CrossRef]

19. Ehui, S.K.; Spencer, D.S.C. Measuring the sustainability and economic viability of tropical farming systems: A model from sub-Saharan Africa. Agric. Econ. 1993, 9, 279-296. [CrossRef]

20. Figge, F.; Hahn, T. Sustainable value added-Measuring corporate contributions to sustainability beyond eco-efficiency. Ecol. Econ. 2004, 48, 173-187. [CrossRef]

21. Gaitán-Cremaschi, D.; Kamali, F.P.; van Evert, F.K.; Meuwissen, M.P.M.; Oude Lansink, A.G.J.M. Benchmarking the sustainability performance of the Brazilian non-GM and GM soybean meal chains: An indicator-based approach. Food Policy 2015, 55, 22-32. [CrossRef]

22. Van Evert, F.; Gaitán-Cremaschi, D.; Fountas, S.; Kempenaar, C. Can precision agriculture increase the profitability and sustainability of the production of potatoes and olives? Sustainability 2017, 9, 1863. [CrossRef]

23. Van Passel, S.; Nevens, F.; Mathijs, E.; Van Huylenbroeck, G. Measuring farm sustainability and explaining differences in sustainable efficiency. Ecol. Econ. 2007, 62, 149-161. [CrossRef]

24. Stern, D.I. The capital theory approach to sustainability: A critical appraisal. J. Econ. Issues 1997, 31, $145-174$. [CrossRef]

25. Hartridge, O.; Pearce, D. Is UK Agriculture Sustainable? Environmentally Adjusted Economic Accounts for UK Agriculture; CSERGE, University College: London, UK, 2001.

26. Pimentel, D.; Marklein, A.; Toth, M.A.; Karpoff, M.N.; Paul, G.S.; McCormack, R.; Kyriazis, J.; Krueger, T. Food versus biofuels: Environmental and economic costs. Hum. Ecol. 2009, 37, 1-12. [CrossRef]

27. Pretty, J.N.; Brett, C.; Gee, D.; Hine, R.E.; Mason, C.F.; Morison, J.I.L.; Raven, H.; Rayment, M.D.; van der Bijl, G. An assessment of the total external costs of UK agriculture. Agric. Syst. 2000, 65, 113-136. [CrossRef]

28. Pretty, J.N.; Ball, A.S.; Lang, T.; Morison, J.I.L. Farm costs and food miles: An assessment of the full cost of the UK weekly food basket. Food Policy 2005, 30, 1-19. [CrossRef]

29. Tegtmeier, E.M.; Duffy, M.D. External costs of agricultural production in the United States. Int. J. Agric. Sustain. 2004, 2, 1-20. [CrossRef]

30. Ball, V.E.; Lovell, C.A.K.; Luu, H.; Nehring, R. Incorporating environmental impacts in the measurement of agricultural productivity growth. J. Agric. Resour. Econ. 2004, 29, 436-460.

31. Beltrán-Esteve, M.; Gómez-Limón, J.A.; Picazo-Tadeo, A.J.; Reig-Martínez, E. A metafrontier directional distance function approach to assessing eco-efficiency. J. Product. Anal. 2014, 41, 69-83. [CrossRef] 
32. Hoang, V.-N.; Coelli, T. Measurement of agricultural total factor productivity growth incorporating environmental factors: A nutrients balance approach. J. Environ. Econ. Manag. 2011, 62, 462-474. [CrossRef]

33. Pérez Urdiales, M.; Lansink, A.O.; Wall, A. Eco-efficiency among dairy farmers: The importance of socio-economic characteristics and farmer attitudes. Environ. Resour. Econ. 2016, 64, 559-574. [CrossRef]

34. Picazo-Tadeo, A.J.; Gómez-Limón, J.A.; Reig-Martínez, E. Assessing farming eco-efficiency: A data envelopment analysis approach. J. Environ. Manag. 2011, 92, 1154-1164. [CrossRef] [PubMed]

35. Picazo-Tadeo, A.J.; Beltrán-Esteve, M.; Gómez-Limón, J.A. Assessing eco-efficiency with directional distance functions. Eur. J. Oper. Res. 2012, 220, 798-809. [CrossRef]

36. Füsun Tatlıdil, F.; Boz, İ.; Tatlidil, H. Farmers' perception of sustainable agriculture and its determinants: A case study in Kahramanmaras province of Turkey. Environ. Dev. Sustain. 2009, 11, 1091-1106. [CrossRef]

37. Galdeano-Gomez, E.; Zepeda-Zepeda, J.A.; Piedra-Munoz, L.; Vega-Lopez, L.L. Family farm's features influencing socio-economic sustainability: An analysis of the agri-food sector in southeast Spain. New Medit. 2017, 16, 50-62.

38. Binam, J.N.; Sylla, K.; Diarra, I.; Nyambi, G. Factors affecting technical efficiency among coffee farmers in Cote d'Ivoire: Evidence from the centre west region. Afr. Dev. Rev. 2003, 15, 66-76. [CrossRef]

39. Khai, H.V.; Yabe, M. Technical efficiency analysis of rice production in Vietnam. J ISSAAS 2011, 17, $135-146$.

40. Rios, A.R.; Shively, G.E. Farm size, irrigation infrastructure, and the efficiency of coffee production in Vietnam. For. Trees Livelihoods 2006, 16, 397-412. [CrossRef]

41. Chambers, R.G.; Chung, Y.; Färe, R. Profit, directional distance functions, and Nerlovian efficiency. J. Optim. Theory Appl. 1998, 98, 351-364. [CrossRef]

42. Färe, R.; Grosskopf, S. New Directions: Efficiency and Productivity; Springer Science \& Business Media: New York, NY, USA, 2006; p. 174, ISBN 9780387249636.

43. Fried, H.O.; Lovell, C.K.; Schmidt, S.S.; Schmidt, S.S. The Measurement of Productive Efficiency and Productivity Growth; Oxford University Press: New York, NY, USA, 2008; p. 656, ISBN 9780195183528.

44. McWhinnie, S.; Otumawu-Apreku, K. Profit Efficiency of the South Australian Rock Lobster Fishery: Nerlovian and Directional Distance Function Approach; Research Paper; The University of Adelaide School of Economics Australia: Adelaide, Australia, October 2013.

45. Chung, Y.H.; Färe, R.; Grosskopf, S. Productivity and undesirable outputs: A directional distance function approach. J. Environ. Manag. 1997, 51, 229-240. [CrossRef]

46. Jayaraman, A.R.; Srinivasan, M.R. Analyzing profit efficiency of banks in India with undesirable output Nerlovian profit indicator approach. IIMB Manag. Rev. 2014, 26, 222-233. [CrossRef]

47. Fox, K.J.; Grafton, R.Q.; Kirkley, J.; Squires, D. Property rights in a fishery: Regulatory change and firm performance. J. Environ. Econ. Manag. 2003, 46, 156-177. [CrossRef]

48. Hailu, A.; Veeman, T.S. Alternative methods for environmentally adjusted productivity analysis. Agric. Econ. 2001, 25, 211-218. [CrossRef]

49. Simar, L.; Wilson, P.W. Estimation and inference in two-stage, semi-parametric models of production processes. J. Econ. 2007, 136, 31-64. [CrossRef]

50. Simar, L.; Wilson, P.W. Two-stage DEA: Caveat emptor. J. Product. Anal. 2011, 36, 205. [CrossRef]

51. D'haeze, D. Quality and Sustainability Improvement of Coffee Production and Trade in Chu Se District, Gia Lai Province. Hanoi: EdE Consulting, 2012. Available online: http:/ /www.defoundation.org/assets (accessed on 15 April 2016).

52. Foreign Agricultural Service, United States Department of Agriculture. Available online: https://gain. fas.usda.gov / Recent\%20GAIN\%20Publications/COFFEE\%20ANNUAL_Hanoi_Vietnam_5-17-2017.pdf (accessed on 9 August 2018).

53. Ahmad, A. An institutional analysis of changes in land use pattern and water scarcity in Dak Lak province, Vietnam. In Institutions, Livelihoods and the Environment: Change and Response in Mainland Southeast Asia with and Introduction by Per Ronnås; NIAS: Copenhagen, Denmark, 2000; ISBN 8787062984.

54. Lindskog, E.; Dow, K.; Axberg, G.N.; Miller, F.; Hancock, A. When Rapid Changes in Environmental, Social and Economic Conditions Converge: Challenges to Sustainable Livelihoods in Dak Lak, Vietnam; Stockholm Environment Institute (SEI): Stockholm, Sweden, 2005; pp. 1-70, ISBN $9197523836,9789197523837$.

55. Wintgens, J.N. Coffee: Growing, Processing, Sustainable production. A Guidebook for Growers, Processors, Traders and Researchers, 2nd ed.; Wiley-VCH: Weinheim, Germany, 2009; pp. 1-983, ISBN 9783527307319. 
56. Intergovernmental Panel on Climate Change (IPCC). Available online: https:/ /www.ipcc-nggip.iges.or.jp / public/2006gl/ (accessed on 15 April 2016).

57. Blonk Consultants. Available online: http://www.blonkconsultants.nl/wpcontent/uploads/"2016/06/ fertilizer_production-D03.pdf (accessed on 15 April 2016).

58. Fertilizers Europe. Available online: https://www.fertilizerseurope.com/get-to-know-us/cool-farm-tool/ (accessed on 15 April 2016).

59. Lal, R. Carbon emission from farm operations. Environ. Int. 2004, 30, 981-990. [CrossRef] [PubMed]

60. Van der Vossen, H. A critical analysis of the agronomic and economic sustainability of organic coffee production. Exp. Agric. 2005, 41, 449-473. [CrossRef]

61. European Environment Agency. Available online: https://www.eea.europa.eu/publications/emep-eeaguidebook-2013 (accessed on 21 April 2016).

62. Glover, N.; Beer, J. Nutrient cycling in two traditional Central American agroforestry systems. Agrofor. Syst. 1986, 4, 77-87. [CrossRef]

63. Hergoualc'h, K.; Skiba, U.; Harmand, J.-M.; Hénault, C. Fluxes of greenhouse gases from andosols under coffee in monoculture or shaded by Inga densiflora in Costa Rica. Biogeochemistry 2008, 89, 329. [CrossRef]

64. Cannavo, P.; Harmand, J.-M.; Zeller, B.; Vaast, P.; Ramírez, J.E.; Dambrine, E. Low nitrogen use efficiency and high nitrate leaching in a highly fertilized Coffea arabica-Inga densiflora agroforestry system: A 15n labeled fertilizer study. Nutr. Cycles Agroecosyst. 2013, 95, 377-394. [CrossRef]

65. Bouwman, A.F.; Boumans, L.J.M.; Batjes, N.H. Modeling global annual n2o and no emissions from fertilized fields. Glob. Biogeochem. Cycles 2002, 16, 28-21-28-29. [CrossRef]

66. Harmand, J.-M.; Ávila, H.; Dambrine, E.; Skiba, U.; de Miguel, S.; Renderos, R.V.; Oliver, R.; Jiménez, F.; Beer, J. Nitrogen dynamics and soil nitrate retention in a Coffea arabica-Eucalyptus deglupta agroforestry system in southern Costa Rica. Biogeochemistry 2007, 85, 125-139. [CrossRef]

67. Cornell University. Available online: https://ecommons.cornell.edu/handle/1813/55750?show=full (accessed on 21 April 2016).

68. Praneetvatakul, S.; Schreinemachers, P.; Pananurak, P.; Tipraqsa, P. Pesticides, external costs and policy options for Thai agriculture. Environ. Sci. Policy 2013, 27, 103-113. [CrossRef]

69. Silalertruksa, T.; Bonnet, S.; Gheewala, S.H. Life cycle costing and externalities of palm oil biodiesel in Thailand. J. Clean. Prod. 2012, 28, 225-232. [CrossRef]

70. Van Grinsven, H.J.M.; Holland, M.; Jacobsen, B.H.; Klimont, Z.; Sutton, M.A.; Jaap Willems, W. Costs and benefits of nitrogen for Europe and implications for mitigation. Environ. Sci. Technol. 2013, 47, 3571-3579. [CrossRef] [PubMed]

71. Leach, A.W.; Mumford, J.D. Pesticide environmental accounting: A method for assessing the external costs of individual pesticide applications. Environ. Pollut. 2008, 151, 139-147. [CrossRef] [PubMed]

72. Pretty, J.; Brett, C.; Gee, D.; Hine, R.; Mason, C.; Morison, J.; Rayment, M.; Van Der Bijl, G.; Dobbs, T. Policy challenges and priorities for internalizing the externalities of modern agriculture. J. Environ. Plan. Manag. 2001, 44, 263-283. [CrossRef]

73. Coelli, T.J.; Battese, G.E. Identification of Factors which Influence the Technical Inefficiency of Indian Farmers. Aust. J. Agric. Econ. 1996, 40, 103-128. [CrossRef]

74. So, O. Productivity and technical efficiency of poultry egg production in Nigeria. Int. J. Poult. Sci. 2003, 2, 459-464.

75. Dhungana, B.R.; Nuthall, P.L.; Nartea, G.V. Measuring the economic inefficiency of Nepalese rice farms using data envelopment analysis. Aust. J. Agric. Resour. Econ. 2004, 48, 347-369. [CrossRef]

76. Nchare, A. Analysis of Factors Affecting Technical Efficiency of Arabica Coffee Producers in Cameroon; AERC research paper 163; AERC: Nairobi, Kenya, 2007.

77. Alwarritzi, W.; Nanseki, T.; Chomei, Y. Analysis of the factors influencing the technical efficiency among oil palm smallholder farmers in Indonesia. Procedia Environ. Sci. 2015, 28, 630-638. [CrossRef]

78. Debebe, S.; Haji, J.; Goshu, D.; Edriss, A.K. Technical, allocative, and economic efficiency among smallholder maize farmers in Southwestern Ethiopia: Parametric approach. J. Dev. Agric. Econ. 2015, 7, 282-291. [CrossRef]

79. Tran, C.T. Optimal Investment Decisions of Coffee Farmers in Vietnam. Ph.D. Thesis, University of Western Australia, Perth, Australia, October 2011. 
80. Latruffe, L.; Balcombe, K.; Davidova, S.; Zawalinska, K. Determinants of technical efficiency of crop and livestock farms in Poland. Appl. Econ. 2004, 36, 1255-1263. [CrossRef]

81. Bellamy, A.S. Weed control practices on Costa Rican coffee farms: Is herbicide use necessary for small-scale producers? Agric. Hum. Values 2010, 28, 167-177. [CrossRef]

82. Ho, T.Q.; Hoang, V.-N.; Wilson, C.; Nguyen, T.-T. Which farming systems are efficient for Vietnamese coffee farmers? Econ. Anal. Policy 2017, 56, 114-125. [CrossRef]

83. The World Bank. Coffee Sector in Vietnam; World Bank: Washington, DC, USA, 2004. Available online: http: / / documents.worldbank.org/curated/en/458011468172449689/Vietnam-Coffee-sector-report (accessed on 25 April 2016).

84. Latruffe, L.; Davidova, S.; Balcombe, K. Application of a double bootstrap to investigation of determinants of technical efficiency of farms in Central Europe. J. Product. Anal. 2008, 29, 183-191. [CrossRef]

85. Jansen, D.M. (Agri-Logic, Heelsum, The Netherlands). Personal communication, 2016.

86. Cheesman, J.; Bennett, J. Natural Resources, Institutions and Livelihoods in Dak Lak, Vietnam; The Australian National University: Canberra, Australia, 2005.

87. D’haeze, D.; Deckers, J.; Raes, D.; Phong, T.A.; Minh Chanh, N.D. Over-irrigation of Coffea canephora in the central highlands of Vietnam revisited: Simulation of soil moisture dynamics in rhodic ferralsols. Agric. Water Manag. 2003, 63, 185-202. [CrossRef]

88. Daraio, C.; Simar, L.; Wilson, P.W. Testing whether two-stage estimation is meaningful in non-parametric models of production. 2010, ISBA discussion paper 1031. Available online: https:/ / sites.uclouvain.be/ISBAArchives/ISBApublications/archive/dp2010/DP1031.pdf (accessed on 15 November 2018).

(C) 2018 by the authors. Licensee MDPI, Basel, Switzerland. This article is an open access article distributed under the terms and conditions of the Creative Commons Attribution (CC BY) license (http:// creativecommons.org/licenses/by/4.0/). 